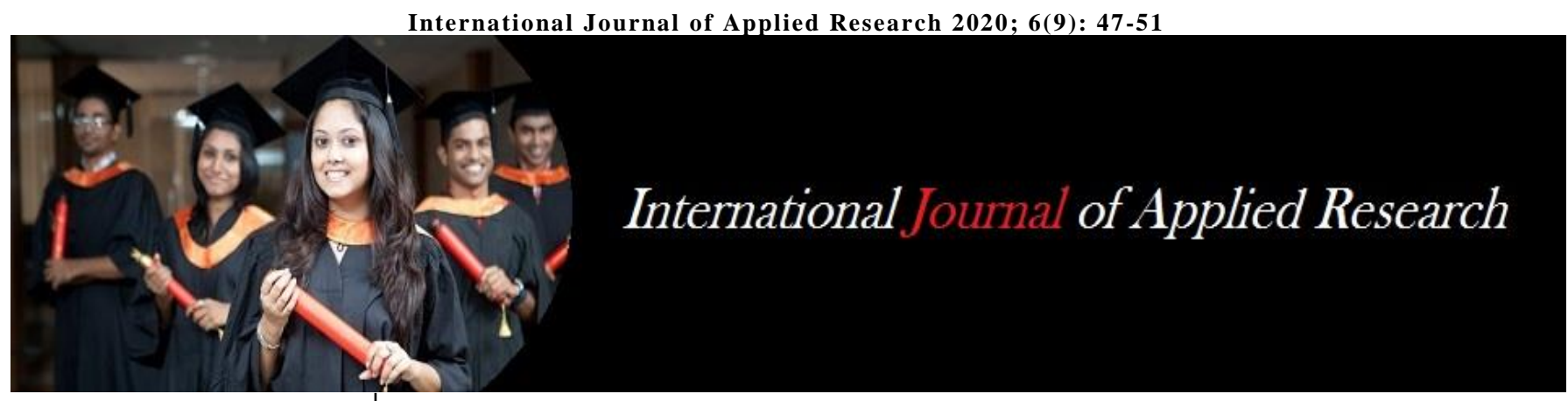

ISSN Print: 2394-7500

ISSN Online: 2394-5869

Impact Factor: 5.2

IJAR 2020; 6(9): 47-51

www.allresearchjournal.com

Received: 17-07-2020

Accepted: 21-08-2020

\section{Peekesh Kumar}

Professor \& HOD, Department

of Psychiatric Nursing, Metro

College of Nursing, Greater

Noida Uttar Pradesh, Maharaj

Vinayak Global University,

Dhand, Jaipur, Rajasthan,

India

\section{Dr. Yogesh Yadav}

Dean/Principal, Maharaj

Vinayak Global University,

Dhand, Jaipur, Rajasthan,

India
Corresponding Author: Dr. Yogesh Yadav Dean/Principal, Maharaj Vinayak Global University, Dhand, Jaipur, Rajasthan, India

\section{Effectiveness of structured teaching programme on knowledge regarding assertive communication and it's benefits in nurse patient relationship among b.sc nursing students in selected nursing colleges at Jaipur}

\author{
Peekesh Kumar and Dr. Yogesh Yadav
}

DOI: https://doi.org/10.22271/allresearch.2020.v6.i9a.7060

\section{Abstract}

Introduction: Communication is usually a two-way process. It is not just giving information or signaling someone; it also involves the comprehension of the information or the signal by the receiver. When the act of giving information or sending message reaches the recipient and gets comprehended by him/her and the receiver sends a feedback as desired by the sender, the process of communication is said to be complete. Communication, therefore, involves more than one person. According to a research by Press Ganey Associates Inc. The nurse patient relationship sets the tone of the care experience and has a powerful impact on patient satisfaction. Nurses spend the most time with patients. Patients are seen nurses' interactions with others on the care team and draw conclusions about the hospital based on their observations. Without a positive nurse patient relationship, there cannot be patient and family satisfaction. Quality of communication in nursing has the highest impact on the life of the patients.

Material and Method: The present study will be conducted in the St. Florence College of Nursing and Institute of medical technology and Nursing Education, Sitapura, Jaipur. In the study 300 samples were selected from the population by using simple random sampling technique. Evaluative approach and quasi experimental one group pre-test and post test design was adopted. Structured knowledge questionnaire were used to collect the data.

Results: Findings revealed that the highest $50 \%$ of the B.Sc. nursing students were in the age group of 21-23 years, $80 \%$ of them were males, $80 \%$ were belongs to Hindu religion, $60 \%$ were belongs to nuclear family, $29 \%$ of the respondents father educated upto Graduate \& $28 \%$ of the respondents mother educated up to senior secondary, $86 \%$ were not having previous knowledge about assertive communication and finally $42 \%$ were receiving information from their teachers. During Post-test $10.0 \%$ of the respondents have moderate knowledge level and $90.0 \%$ of the respondents have gain adequate knowledge level on Assertive Communication and Its Benefits in Nurse Patient Relationship after structured teaching program. The overall mean score was 32.20 plus or minus 4.90 in post-test of B.Sc. Nursing Students which was higher than the overall mean score 11.22 plus or minus 3.97 in pretest. overall improvement in mean score was 20.98 (0.93) with paired t-value 91.44 . The mean post-test knowledge score was significantly higher than the mean pre-test knowledge scores of B.Sc. Nursing students, t-value is $59=2.39, p<.0 .05$ level. Thus, the research hypothesis was accepted.

Conclusion: Students have less moderate Knowledge level and none of them have adequate knowledge about assertive communication. So, after highly recommendation of structured teaching programme adequate knowledge level of the B.Sc. Nursing Students are high.

Keywords: Knowledge, assertive communication, B.Sc. nursing students, nurse patient relationships

\section{Introduction}

Communication is a continuous and dynamic process involving more than one person. It is a cyclic process denoting continuous flow of information. It essentially involves a sender, message and recipient. The sender conceives ideas and encodes them into a suitable medium (facts, figures, pictures), sends them through appropriate channel (email, phone, speech) to the recipient. The recipient decodes the message, understands it and encodes feedback and sends it to the sender. The process continues ${ }^{[3]}$.

The communication process is classified into different types based on certain criteria like the channels used for communication, style of communication, and relationship of the communicators. One such communication is therapeutic communication. 
It is a process in which the nurse consciously influences a client or helps the client to a better understanding. Assertiveness is the ability to express one's feelings, opinions, beliefs, and needs directly, openly and honestly, while not violating the personal rights of others. Assertive staff nurses are able to present suggestions in a direct, comfortable way, give and take criticism, assess the rights and responsibilities in a nursery situation, and act on assessments in a thoughtful problem-solving way. When nurses express a lack of confidence and a lack of assertiveness, patients may notice.

\section{Material and Methods}

An evaluative approach was used as appropriate one for present study. The main aim of this study was to find the effectiveness of structured teaching programme on knowledge regarding assertive communication as in form of nurse patient relationship by comparing pre-test and posttest knowledge score. To associate the pre tests mean knowledge score with selected socio demographic variables of B.Sc. nursing students.

\section{Results}

Section A: Percentage distribution of socio-demographic variables of the subjects

Table 1: Frequency and percentage distribution of Respondents by Age in years $\mathrm{N}=300$

\begin{tabular}{|c|c|c|c|}
\hline S No & Age & Frequency & Percentage \\
\hline 1. & $18-20$ Years & 110 & $37.0 \%$ \\
\hline 2. & $21-23$ Years & 150 & $50.0 \%$ \\
\hline 3. & $24-26$ Years & 40 & $13.0 \%$ \\
\hline \multicolumn{2}{|c|}{ Total } & 300 & $100 \%$ \\
\hline
\end{tabular}

Table: 1 show that out of 300 students, 110 students (37.0\%) belong to age group of $18-20$ years, 150 students $(50.0 \%)$ belong to age group of 21-23 years, and 40 students (13.0\%) belong to the age group of 24-26 years.

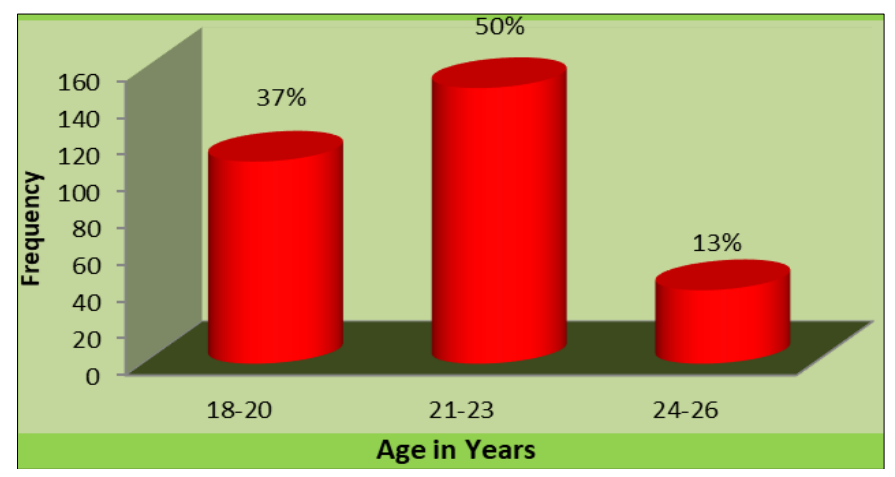

Fig 1: Distribution of students according to Age in years

Table 2: Frequency and percentage distribution of Respondents by Gender

$\mathrm{N}=300$

\begin{tabular}{|c|c|c|c|}
\hline S No & Gender & Frequency & Percentage \\
\hline 1. & Male & 240 & $80.0 \%$ \\
\hline 2. & Female & 60 & $20.0 \%$ \\
\hline \multicolumn{2}{|c|}{ Total } & 300 & $100 \%$ \\
\hline
\end{tabular}

Table: 2 show that out of 300 students, 240 students $(80.0 \%)$ belong to Male Gender, 60 students $(20.0 \%)$ belong to Female Gender.

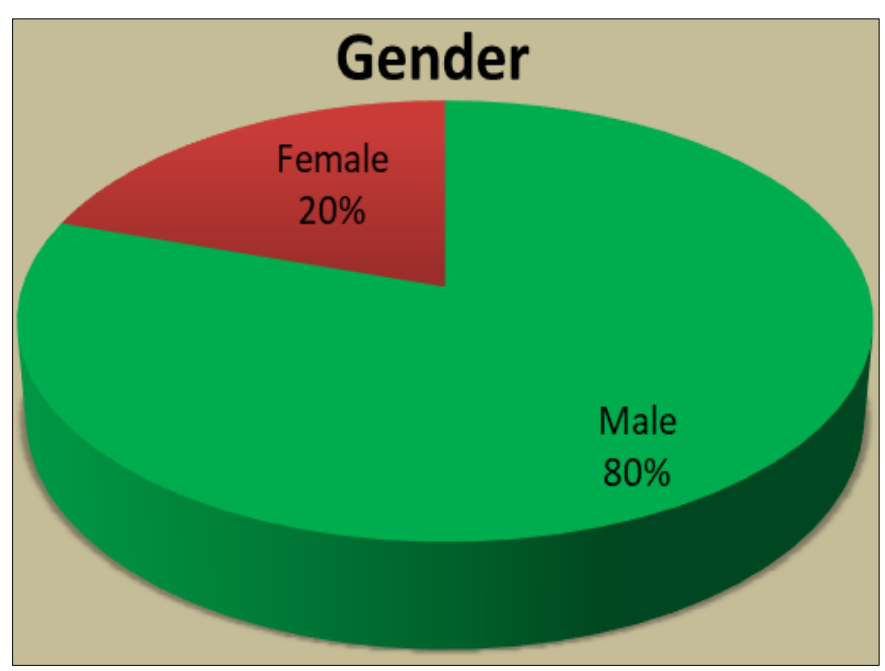

Fig 2: Distribution of students according to Gender

Table 3: Frequency and percentage distribution of Respondents by Previous knowledge about Assertive communication

$\mathrm{N}=300$

\begin{tabular}{|c|c|c|c|}
\hline $\begin{array}{c}\text { S } \\
\text { No }\end{array}$ & $\begin{array}{l}\text { Previous knowledge about } \\
\text { Assertive communication }\end{array}$ & Frequency & Percentage \\
\hline 1. & Yes & 42 & $14.0 \%$ \\
\hline 2. & No & 258 & $86.0 \%$ \\
\hline & Total & 300 & $100 \%$ \\
\hline
\end{tabular}

Table 3: Previous knowledge shows that out of 300 students $258(86.0 \%)$ of respondents were not having previous knowledge about assertive communication and 42 (14.0\%) of the respondents were having previous knowledge about assertive communication. It was inferred that majority of B.Sc. Nursing students were not having previous knowledge about assertive communication.

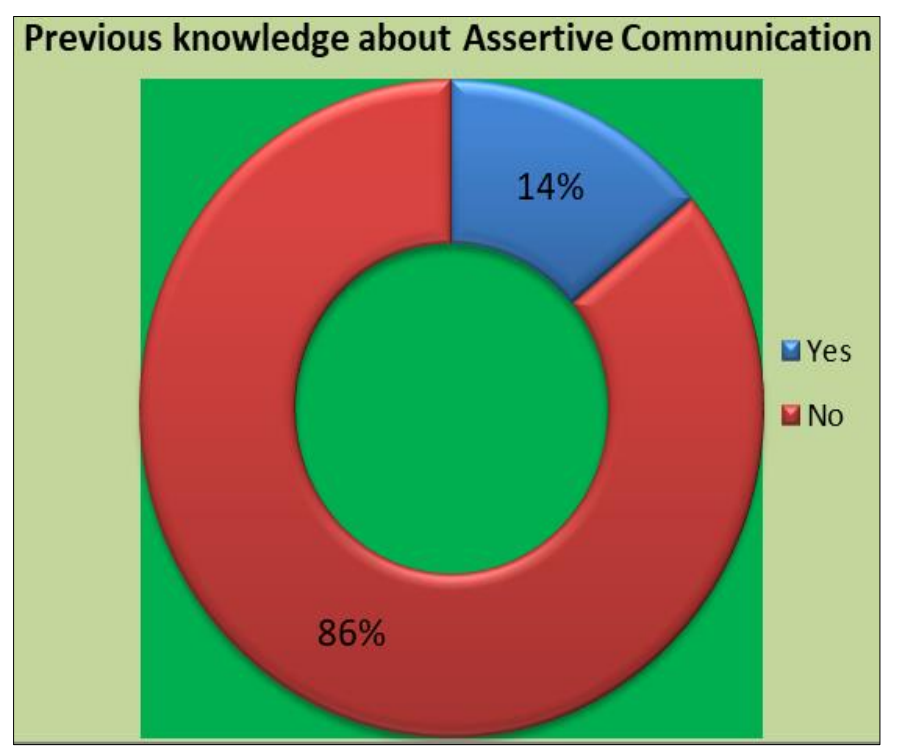

Fig 3: Distribution of students according to previous knowledge 
Table 4: Frequency and percentage distribution of Respondents by source of Information

$\mathrm{N}=300$

\begin{tabular}{|c|c|c|c|}
\hline S. No & Source of Information & Frequency & Percentage \\
\hline 1. & Teachers & 125 & $42.0 \%$ \\
\hline 2. & Friends & 75 & $25.0 \%$ \\
\hline 3. & Relatives & 30 & $10.0 \%$ \\
\hline 4. & Mass media & 70 & $23.0 \%$ \\
\hline \multicolumn{2}{|c|}{ Total } & 300 & $100 \%$ \\
\hline
\end{tabular}

Table 4: Source of Information shows that out of 300 students $125(42.0 \%)$ of respondents were receiving the information from their teachers; 75 (25.0\%) of the respondents were receiving information through their friends; $30(10.0 \%)$ of them through relatives and finally 70 $(23.0 \%)$ of the respondents through mass media. It was

inferred that majority of B.Sc. Nursing Students were receiving information through their teachers.

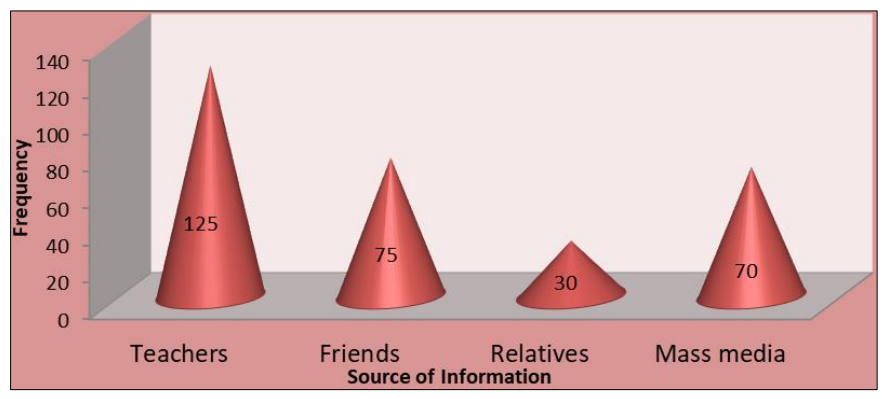

Fig 4: Distribution of students according to source of information

\section{Section B}

Table 5: Data Shows the Association between Pre-test Knowledge Scores on Assertive Communication and Its Benefits in Nurse Patient Relationship and Selected Socio-Demographic Variables.

\begin{tabular}{|c|c|c|c|c|c|c|c|c|}
\hline \multirow{3}{*}{$\mathbf{S N}$} & \multirow{3}{*}{ Variable } & \multirow{3}{*}{ Category } & \multicolumn{5}{|c|}{ Knowledge scores } & \multirow{3}{*}{$\begin{array}{c}\text { value } \\
\text { (p-value) }\end{array}$} \\
\hline & & & \multicolumn{2}{|c|}{ Inadequate } & \multicolumn{2}{|c|}{ Moderate } & \multirow[b]{2}{*}{ Total } & \\
\hline & & & f & $\%$ & $\mathbf{f}$ & $\%$ & & \\
\hline \multirow{3}{*}{1.} & \multirow{3}{*}{$\begin{array}{c}\text { Age } \\
\text { (In Years) }\end{array}$} & $18-20$ & 105 & 35.0 & 05 & 2.0 & 110 & \multirow{3}{*}{$\begin{array}{c}0.51 \\
(0.78)_{\mathrm{NS}}\end{array}$} \\
\hline & & $21-23$ & 142 & 47.0 & 08 & 3.0 & 150 & \\
\hline & & $24-26$ & 37 & 12.0 & 03 & 1.0 & 40 & \\
\hline \multirow{2}{*}{2.} & \multirow{2}{*}{ Gender } & Male & 230 & 77.0 & 10 & 3.0 & 240 & \multirow{2}{*}{$\begin{array}{c}0.08 \\
(0.78)_{\mathrm{NS}}\end{array}$} \\
\hline & & Female & 57 & 19.0 & 03 & 1.0 & 60 & \\
\hline \multirow{4}{*}{3.} & \multirow{4}{*}{ Religion } & Hindu & 232 & 77.4 & 08 & 2.67 & 240 & \multirow{4}{*}{$\begin{array}{c}4.5048 \\
(0.21) \mathrm{NS}\end{array}$} \\
\hline & & Muslim & 33 & 11.0 & 02 & 0.67 & 35 & \\
\hline & & Christian & 18 & 6.0 & 02 & 0.67 & 20 & \\
\hline & & Sikh & 05 & 1.68 & - & - & 05 & \\
\hline \multirow{2}{*}{4.} & \multirow{2}{*}{ Type of Family } & Nuclear & 172 & 57.4 & 08 & 2.6 & 180 & \multirow{2}{*}{$\begin{array}{c}0.23 \\
(0.63)_{\mathrm{NS}}\end{array}$} \\
\hline & & Joint & 116 & 38.7 & 04 & 1.3 & 120 & \\
\hline \multirow{6}{*}{5.} & \multirow{6}{*}{ Education of Father } & Illiterate & 17 & 5.7 & - & - & 17 & \multirow{6}{*}{$\begin{array}{c}21.21 \\
(0.06)_{\mathrm{NS}}\end{array}$} \\
\hline & & Primary & 20 & 6.7 & 02 & 0.6 & 22 & \\
\hline & & Secondary & 50 & 16.7 & 03 & 1.0 & 53 & \\
\hline & & Senior secondary & 69 & 23.0 & 05 & 1.6 & 74 & \\
\hline & & Graduation & 80 & 26.7 & 06 & 2.0 & 86 & \\
\hline & & Post graduation & 45 & 15.0 & 03 & 1.0 & 48 & \\
\hline \multirow{6}{*}{6.} & \multirow{6}{*}{ Education of Mother } & Illiterate & 22 & 7.3 & - & - & 22 & \multirow{6}{*}{$\begin{array}{c}20.09 \\
(0.049)_{\mathrm{NS}}\end{array}$} \\
\hline & & Primary & 16 & 5.3 & 02 & 0.7 & 18 & \\
\hline & & Secondary & 76 & 25.3 & 04 & 1.3 & 80 & \\
\hline & & Senior secondary & 80 & 26.7 & 04 & 1.3 & 84 & \\
\hline & & Graduation & 52 & 17.4 & 04 & 1.3 & 56 & \\
\hline & & Post graduation & 37 & 12.4 & 03 & 1.0 & 40 & \\
\hline \multirow{2}{*}{7.} & \multirow{2}{*}{ Previous knowledge about assertive communication } & Yes & 40 & 13.3 & 02 & 0.7 & 42 & \multirow{2}{*}{$\begin{array}{c}17.45 \\
(0.467)_{\mathrm{NS}}\end{array}$} \\
\hline & & No & 248 & 82.7 & 10 & 3.3 & 258 & \\
\hline & & Teachers & 119 & 39.7 & 06 & 2.0 & 125 & \\
\hline & & Friends & 69 & 23.0 & 06 & 2.0 & 75 & 4.24 \\
\hline 8. & Source of Information & Relatives & 27 & 9.0 & 03 & 1.0 & 30 & $(0.29)_{\mathrm{NS}}$ \\
\hline & & Mass media & 65 & 21.7 & 05 & 1.6 & 70 & \\
\hline
\end{tabular}

\section{Section C}

Table 6: Distribution of Overall Respondent Knowledge Level on Assertive Communication and its Benefits in Nurse Patient Relationship in Pre-test.

$$
\mathrm{N}=300
$$

\begin{tabular}{|c|c|c|c|c|c|}
\hline \multicolumn{2}{|c|}{$\begin{array}{c}\text { Inadequate } \\
\text { Knowledge } \\
(\mathbf{0}-\mathbf{1 3})\end{array}$} & \multicolumn{2}{c|}{$\begin{array}{c}\text { Moderate } \\
\text { Knowledge } \\
(\mathbf{1 4}-\mathbf{2 6})\end{array}$} & \multicolumn{2}{c|}{$\begin{array}{c}\text { Adequate } \\
\text { Knowledge } \\
(\mathbf{2 7}-\mathbf{4 0})\end{array}$} \\
\hline $\mathrm{N}$ & $\%$ & $\mathrm{~N}$ & $\%$ & $\mathrm{~N}$ & $\%$ \\
\hline 260 & 86.7 & 40 & 13.3 & - & - \\
\hline
\end{tabular}

Table 6: reveals the distribution of overall respondent knowledge level regarding Assertive Communication and Its Benefits in Nurse Patient Relationship before structured teaching program.

From the above table shows that $86.7 \%$ of respondents have inadequate knowledge level; $13.3 \%$ of the respondents have moderate knowledge level and finally none of the respondents have adequate knowledge on Assertive Communication and Its Benefits in Nurse Patient Relationship before structured teaching program. 


\section{Section D}

Table 7: Distribution of Overall Respondent Knowledge Level on Assertive Communication and its Benefits in Nurse Patient Relationship in Post-test.

\begin{tabular}{|c|c|c|c|c|c|}
\hline \multicolumn{2}{|c|}{$\begin{array}{c}\text { Inadequate } \\
\text { Knowledge } \\
(\mathbf{0}-\mathbf{1 3})\end{array}$} & \multicolumn{2}{c|}{$\begin{array}{c}\text { Moderate } \\
\text { Knowledge } \\
(\mathbf{1 4}-\mathbf{2 6})\end{array}$} & \multicolumn{2}{c|}{$\begin{array}{c}\text { Adequate } \\
\text { Knowledge } \\
(\mathbf{2 7}-\mathbf{4 0})\end{array}$} \\
\hline $\mathrm{N}$ & $\%$ & $\mathrm{~N}$ & $\%$ & $\mathrm{~N}$ & $\%$ \\
\hline- & - & 30 & 10.0 & 270 & 90.0 \\
\hline
\end{tabular}

Table 7: reveals the distribution of overall respondent knowledge level regarding Assertive Communication and Its

Benefits in Nurse Patient Relationship after structured teaching program.

From the above table shows that $10.0 \%$ of the respondents have moderate knowledge level and $90.0 \%$ of the respondents have gain adequate knowledge level on Assertive Communication and Its Benefits in Nurse Patient Relationship after structured teaching program.

It was inferred that majority of B.Sc. Nursing Students in selected Nursing Colleges At Jaipur; overall the structured teaching program was very effective to enhance knowledge level on Assertive Communication and Its Benefits in Nurse Patient Relationship.

\section{Section E}

Table 8: Mean and Standard deviation of different sections of knowledge on Assertive Communication and its Benefits in Nurse Patient Relationship among B.Sc. Nursing Students in Pre-test and Post-test.

\begin{tabular}{|c|c|c|c|c|c|c|c|}
\hline \multirow{2}{*}{\begin{tabular}{c|c} 
S \\
No.
\end{tabular}} & \multirow{2}{*}{ Different sections of Knowledge } & \multicolumn{2}{|c|}{ Pre-test } & \multicolumn{2}{|c|}{ Post-test } & \multirow{2}{*}{ t-value } & \multirow{2}{*}{$\begin{array}{c}\text { p- } \\
\text { value }\end{array}$} \\
\hline & & Mean & SD & Mean & SD & & \\
\hline 1. & Knowledge assessment regarding Information on general communication & 9.76 & 1.50 & - & - & -1 & - \\
\hline 2. & Knowledge assessment regarding assertive communication & $20.34^{\#}$ & 2.041 & $19.67^{\# \#+1}$ & 1.83 & $0.724 * *$ & $0.043^{*}$ \\
\hline 3. & $\begin{array}{c}\text { Knowledge assessment regarding benefits of assertive communication in nurse patient } \\
\text { relationship }\end{array}$ & - & - & 33.60 & 2.53 & - & - \\
\hline & Overall & 11.22 & 3.97 & 32.20 & 4.90 & 91.44 & $0.03 *$ \\
\hline
\end{tabular}

\# 40 students, \#\# 30 students

** exclude 10 students not common in Pre-Test and Post Test,

*Significant.

Table 9: depicts Mean, Standard deviation of aspect wise knowledge of B.Sc. Nursing Students in pre-test and posttest. B.Sc. Nursing Students obtained the highest mean in assertive communication in post-test (33.60 plus or minus 2.53) when compared with pre-test $(20.34$ plus or minus 2.04).

The overall mean score was 32.20 plus or minus 4.90 in post-test of B.Sc. Nursing Students which was higher than the overall mean score 11.22 plus or minus 3.97 in pre-test. Thus it indicates that there is an enhancement of knowledge among B.Sc. Nursing Students regarding Assertive Communication and Its Benefits in Nurse Patient Relationship.

Results reveals that the overall improvement in mean score was 20.98 (0.93) with Paired t-value 91.44. The mean posttest knowledge score was significantly higher than the mean pre-test knowledge scores of B.Sc. Nursing Students at $p<$ 0.05 level. Thus, the research hypothesis was accepted.

\section{Section F}

Table 9: Mean difference and Standard Deviation difference Pre-test and Post-test by using Paired t-test (Effectiveness of Structured Teaching Programme)

\begin{tabular}{|c|c|c|c|c|}
\hline \multirow{2}{*}{$\begin{array}{c}\text { S. } \\
\text { No. }\end{array}$} & Different sections of Knowledge & \multicolumn{2}{c|}{$\begin{array}{l}\text { Inadequate Knowledge (0 - 13) } \\
\text { Moderate Knowledge (14 - 26) } \\
\text { Adequate Knowledge (27 - 40) }\end{array}$} & $\begin{array}{c}\text { Paired t-value } \\
\text { Mean Diff. }\end{array}$ \\
\cline { 2 - 5 } & & 9.76 & 1.50 & \\
\hline 1. & Knowledge assessment regarding Information on general communication & - \\
\hline 2. & Knowledge assessment regarding assertive communication & 0.67 & 0.21 & $0.724^{* *}\left(0.043^{*}\right)$ \\
\hline \multirow{2}{*}{3.} & $\begin{array}{c}\text { Knowledge assessment regarding benefits of assertive communication in } \\
\text { nurse patient relationship }\end{array}$ & 33.60 & 2.53 & \\
\hline & Overall & 20.98 & 0.93 & $91.44\left(0.03^{*}\right)$ \\
\hline
\end{tabular}

Table: 9 Reveals that the overall improvement in mean score was $20.98(0.93)$ with paired t-value 91.44 . The mean post-test knowledge score was significantly higher than the mean pre-test knowledge scores of B.Sc. Nursing students, $\mathrm{t}$-value is $59=2.39, p<.0 .05$ level. Thus, the research hypothesis was accepted.

Table 10: Correlation

\begin{tabular}{|c|c|c|c|}
\hline S No. & Different sections of Knowledge & Pre-test & Post-test \\
\hline 2. & Knowledge assessment regarding assertive communication & $0.839(0.029 *)$ \\
\hline
\end{tabular}

*Significant Relationship between Pre-Test and Post Test.

This study reveals that correlation between pre-test and post-test score in knowledge assessment on assertive communication found to be $0.839(0.029 *)$ more effective, so in this study teaching programme become more effective in assertive communication. 


\section{Discussion}

The present study was conducted to assess the effectiveness of structured teaching programme on knowledge regarding assertive communication and its benefits in nurse patient relationship among B.Sc. nursing students in selected nursing colleges at Jaipur.

In order to achieve the objectives of the study, one group pre-test and post-design with Pre-experimental design was adopted. The sample comprised of 300 B.Sc. nursing students. The data were collected from them before and after the administration of structured teaching program using a structured questionnaire.

\section{The objectives of the study}

1. To assess pre test levels of knowledge on assertive communication and its benefits in nurse patient relationship of B.Sc. nursing students.

2. To assess post test levels of knowledge on assertive communication and its benefits in nurse patient relationship of B.Sc nursing students.

3. To evaluate the effectiveness of STP on assertive communication and its benefits in NPR by comparing the differences between the pre test and post test knowledge scores.

4. To associate the pre tests mean knowledge score with selected socio demographic variables of B.Sc nursing students.

The study attempted to test the following Hypothesis:

$\mathbf{R H}_{1}$ : There will be a significant difference between the mean pre-test and post-test knowledge scores.

$\mathbf{R H}_{2}$ : There will be a significant association between pretest knowledge scores with selected demographic variables.

In the present study distribution of overall respondent knowledge level regarding Assertive Communication and Its Benefits in Nurse Patient Relationship after structured teaching program. $10.0 \%$ of the respondents have moderate knowledge level and $90.0 \%$ of the respondents have gain adequate knowledge level on Assertive Communication and Its Benefits in Nurse Patient Relationship after structured teaching program.

\section{Conclusion}

This presents study concluded that implications to nursing fields, limitations, and delimitations with study designs and methods and recommendations of the study. The focus of this study was to assess the effectiveness of structured teaching programme on knowledge of assertive communication and its benefits in nurse patient relationship among B.Sc Nursing students at St. Florence college of Nursing and Institute of Medical Technology and Nursing Education, Sitapura at Jaipur.

\section{The following conclusions were drawn from the Pre-test and post test of the study}

Findings revealed that the highest $50 \%$ of the B.Sc. nursing students were in the age group of 21-23 years, $80 \%$ of them were males, $80 \%$ were belongs to Hindu religion, $60 \%$ were belongs to nuclear family, $29 \%$ of the respondents father educated upto graduate $\& 28.0 \%$ of the respondents mother educated up to senior secondary, $86.0 \%$ were not having previous knowledge about assertive communication and finally $42.0 \%$ were receiving information from their teachers.
It was inferred that the socio-demographic factors such as age, gender, religion, types of family, education of father \& education of mother, previous knowledge about assertive communication and finally sources of information of the respondents shows there is a significant association between the Pre-test knowledge level and socio-demographic variables $(\mathrm{P}>0.05)$.

\section{References}

1. Monika K, Jolanta K et al. Analysis of selected socio demographic factors affecting assertive behaviours among nurses and students of nursing. Problem y Pielęgniarstwa. 2019; 27(1):12-19.

2. Behire S, Demet A. The relationship between levels of Alexithymia and communication skills of nursing students. Pak J Med Sci. 2019; 35(2):489-494.

3. Patel JM, Suresh V, et al. Assess the effectiveness of assertive training programme on assertive behavior among adolescents. International Journal of Scientific Research. 2019; 8(7):40-42.

4. Kanade A. The effect of assertiveness training program on nurses. Indian J Psy Nsg. 2018; 15(2):19-23.

5. Gultekin A, Ozdemir AA et al. The effect of assertiveness education on communication skills given to nursing students. International Journal of caring sciences. 2018; 11(1):395-402.

6. Larijani, Taraneh $\mathrm{T}$ et al. Assertiveness and the Factors affecting it Among Nursing Students of Tehran University of Medical Sciences. International Journal of New Technology and Research, 2017, 3(5).

7. Yohei N, Naoki Y et al. Development and evaluation of a modified brief assertiveness training for nurses in the workplace: a single-group feasibility study" Nakamura et al. BMC Nursing. 2016; 16:29.

8. Jones TL, Stone TE et al. The effectiveness of assertiveness communication training programs for health care professionals and students. International Journal of Nursing studies. 2017; 76(2):120-28.

9. Clement I. Text book on communication and educational technology. $1^{\text {st }}$ ed; EMMESS medical publishers, Bengaluru, 2008.

10. Poilt DF, Hungler BP. Text book of principles and practice, Lippincott publications, Philadelpia, 1999, 657-58.

11. Kothari. Research methodology: method and technique. Google result, 2008.

12. Available from: URL: http//www.books.google.co.in

13. Polit DF, Hungler BP. Nursing Research: Principles and Methods. $6^{\text {th }}$ edition. Philadelphia. JB Lippincott, 1999. 